Dubravka Đurić

Singidunum University Belgrade

\title{
The Language Poetry Experiment and the Transformation of the Canon ${ }^{1}$
}

American language poetry was the most important form of experimental poetry formation to appear in the 1970s. It challenged our way of writing poetry and thinking about it, and impacted the transformation of the canon of American poetry. My intention in this article is to conceptualize the work of these poets through several "turns": the linguistic, the cultural, the performative, and the global/neoliberal turn.

Key words: cultural turn, experimental poetry, neoliberalism, language poetry, linguistic turn, performative turn

The phenomenon of American language poetry now belongs to history. According to many of its interpreters, it was the most important experimental poetry to appear in the United States during the last three decades of the twentieth century. The importance and complexity of the work of these poets impacted the transformation of the very field of poetry. The language poets $^{2}$ reshaped the canon of American poetry, and they did this by reshaping the practice of writing poetry, as well as the practice of thinking about and interpreting poetry. They position themselves on the political left and consider their work to be political. Their work from the 1970s to late 1990s went through several important turns, from the language turn to the performative and cultural turns to the global turn, which I will discuss below.

At the beginning, it should be said that we might think of language

1 This text was written as a part of MPRTNRS project no. 178029.

2 Charles Bernstein, Ron Silliman, Barrett Watten, Lyn Hejinian, and Michael Davidson, to mention some of them. 
poetry as a poetry formation, to use Alan Golding's words, in the same way that Raymond Williams defined the social formation as "those effective movements and tendencies, in intellectual and artistic life, which have significant and sometimes decisive influence on the active development of a culture, and which have a variable and often oblique relation to formal institutions" (Williams 117). The concept of social formation in language poetry is interwoven with the interest in innovative forms (Watten 2015: 241). Language poets' work can be situated in the "social momentum of post-1945 countercultural literary movements" as well as their precursors the Beat poets, the New York School, or the Black Mountain College poets (Watten 2015:241), all of whom are known under the umbrella term New American Poetry. Language poets connected "oppositional politics and cultural views with linguistically inventive writing" (Bernstein 286), which was at odds with earlier left-wing poets who were interested in representational and populist approaches to poetry (ibid.). This meant that, for them, it was not important just what poetry is or what it does, but also how it works, and this how led them to consider poetry as a social activity, in which the commitment to the community formation was important and performed through intensive mutual interaction (Bernstein 282). The interaction was realized thanks to the established alternative network of publishing and editing, which made it possible for them to produce alternative concepts of poetry, ways of reading, and literary histories. All these were possible because of the technical revolution which enabled the proliferation of small presses, little magazines, and book editions, a tendency that started in the 1950s and reached its peak with the language poets. Oren Izenberg explains:

Language poetry has, since its inscription in 1971, devoted a significant portion of its energies to the construction of an 'alternative' literary culture, founding little magazines such as This, Hills, o-blek, Temblor, $\mathrm{L}=\mathrm{A}=\mathrm{N}=\mathrm{G}=\mathrm{U}=\mathrm{A}=\mathrm{G}=\mathrm{E}$, Poetics Journal, and Aerial, small presses such as Roofs, Potes and Poets, O Book, The Figures, Tuumba, and Sun and Moon, 
and an endless number of mimoes, broadsheets, newsletters, reading series, collaborations, and, of course, conferences. (144)

Language poetry was avant-garde, radical, and experimental. It appeared in the context of the anti-academic field of poetry. If we consider the moment of these poets' appearance diachronically, we see that they were a continuation and at the same time a critique of New American Poetry as a countercultural stream. The movement appeared as an offshoot of New American Poetry, critiquing its bardic, personalistic impulses (Đurić 146). If we look at the synchronic level, language poetry appeared at the same time as the so-called workshop poem, which developed after confessional poetry became the new mainstream. The term workshop poem refers to narrative poetry, which constructs a lyrical I "as the central organizing or ocular point" (Derksen 130). The goal of so many writing programs at various universities where workshop poetry was taught was to promote a poetics of individual voice articulated in regard to a poet's previous experiences and emotions, which were supposed to be authentically expressed in free verse (Rasula 416). In relation to the anti-intellectualism of workshop poetry, language poets developed a highly intellectual approach to the production of poetry.

\section{Language poetry and the linguistic, cultural, and performative turns}

At first, the language poets focused their attention on the very language they used in making the poems. This characteristic made their work part of a linguistic turn in arts and humanities. This direction was emphasized by Ron Silliman, who pointed to Robert Grenier's now famous proclamation "I hate speech" as a starting point for language writing (Silliman 1986b: $\mathrm{xv})$. Grenier's proclamation was a gesture of rejecting the speech-based-poetry of the New Americans as an earlier avant-garde poetry. Referring to the Russian Cubo-Futurist notion of word-as-such, the language poets focused in their work on the "production of material text" (Watten 2003: 44). In other words, like other avant-garde movements, they insisted on the materiality of their techniques, which meant "of a material signifier: language, print, sound 
as the foundation of its genres or media" (Watten 2003: 48). They insisted on the social materiality of the linguistic, which is why this "language centered" writing worked with parataxis, in which connectors between the elements of the sentence have been elided. Silliman introduced the term new sentence, by which he meant the "serial or paratactical ordering of grammatical sentences" (Bernstein 291). Silliman emphasized that the new sentence "is the first mode of 'language writing' which has been able to incorporate all the elements of language, from below the sentence level and above" (Silliman 1986b: 575). In other words, the language poets, according to Silliman, used sentence-centered poems, investigating the sentence, as well as the paragraph and the stanza, or consider the page-as-field, in which the page is a "spatial unit filled with 'desyntaxed' words or phrases” (Silliman 1987: 62). Golding claims:

Writers like Lyn Hejinian, Carla Harryman, and Ron Silliman break down story, argument, and autobiography into narratively and logically discontinuous juxtaposed sentences; they are particularly concerned with how narrative embodies certain ways of constructing the individual self or subject (and thus, implicitly, certain concepts of 'life'), and with investigating Silliman's question: 'How do sentences integrate into the higher units of meaning?' . . . (149)

Poets like Charles Bernstein, Susan Howe, Bruce Andrews, and Barrett Watten worked with different forms of disruption, breaking down "the syntax of sentences into the parataxis of phrases and shifting parts of speech" (Golding 149). These poets broke words into component syllables, disrupted syntax, and worked with typography and the visual aspect of the page.

Here are a few examples. In his work Pcoet, David Melnick worked, in Silliman's terms, with the level below the sentence, which means with the materiality of the signifier:

thoeisu 
thoiea

akcorn woi citrus locquump

icgja... (Melnick 90)

Charles Bernstein's poem “Islets/Irritations” works with the page-asfield, upon which the poet puts words in which syntactical connections are destabilized and questioned:

$\begin{array}{lccr}\begin{array}{l}\text { to proper to } \\ \text { rectilinear }\end{array} & \begin{array}{c}\text { behindless } \\ \text { our plated }\end{array} & \begin{array}{c}\text { weigh in a } \\ \text { embrosserie des petits cocobons }\end{array} \\ \text { pliant feint } & \text { insensate, round } & \text { hands of immense... (Bernstein 1) }\end{array}$

The beginning of Ron Silliman's Tjanting is an example of the poet's working with sentence and paragraph, using procedural forms which are generative. In this sense, Silliman used the rule-governed procedures of "Fibonacci number sequence to determine the number of sentences in each paragraph" (Watkin).

Not this.

What then?

I started over \& over. Not this.

Last week I wrote "the muscles in my palm so sore from halving the rump roast I cld brely grip the pen." What then? This morning my lip is blistered. (Silliman 1986a:11)

Although this focusing on the formal aspects of language writing, which was performed in accordance with the linguistic turn, could appear to be a depoliticizing gesture, what was at stake was the politicization of the poetic. In other words, from the late 1970s through the 1980s and 1990s, 
the language poets worked with the leftist concept of politicization of culture, which they share foremost with Post-Marxism, New Historicism, Cultural Studies, and Cultural Materialism. The crucial issue was that the cultural turn brought in by cultural studies in poetry meant rethinking the category of the aesthetic, which is now understood as an active agent that is in intensive although usually hidden interaction with the political, social, and economic realms (Damon et al. 2). Shaping the post-formalist contextualizing theories of the poetic text (DuPlessis 7), Barrett Watten introduced the notion of social formalism, referring to the way the "social exists in and through its [textual] forms" (Watten, qtd. in DuPlessis 8), and Charles Bernstein's politics of poetic form pointed to "how radically innovative poetic styles can have social meanings" or how "choices of grammar, vocabulary, syntax, and narrative reflect ideology" (Bernstein vii).

As already pointed out, the attention of the language poets was from the beginning directed toward the visual aspect of the printed page, in the tradition of historical avant-garde movements, from Futurism and Cubo-Futurism to Concrete and Visual poetry, but poetry readings were also an important part of their interest. This led them to the discussion of the acoustic aspect of poetry, which I see as the performative turn in their theorizations of poetry, as well as their poetry practice. Although the notion of performance could be applied to the visual outlook of the printed page, and Johanna Drucker has investigated visual performativity (Drucker 1998) in experimental writing, I will focus on the sense of this word which refers to the foregrounding of the acoustic aspect of the reading of poetry, or the sounding of the poem, to use Jerome Rothenberg's term (121). This means that the language poets were aware that twentieth-century innovative poets "work with the sound as material, where sound is neither arbitrary nor secondary, but constitutive" (Bernstein 4). The poem is seen as multiform, due to its different typographic appearances within the printed culture (magazines, books, anthologies) and the oral interpretation of it can be seen as a destabilizing "resistance to textual authority" (Bernstein 10; Đurić 152-53). Pointing to the different attitudes toward reading, Bernstein emphasizes that one group of poets considers the 
reading as "an extension of an authorized and stable written work" (123), while others consider oral interpretation to be quite a different version of the work, and thus develop different performance styles. Emphasizing that, for some contemporary poets, the poetry performance is central to their practice, Bernstein in historical perspective distinguished between the orality of analphabetic cultures and alphabetic ones:

The poetry of analphabetic cultures used prosodic formulas both to aid meaning and to goad composition. Since there were no scripts, literal memorization was inconceivable. Memory, as a poetic practice, involves an active exploration of the unknowable in ways that impart an evanescent presence. Memorization is a postscript technique that requires precise, literal reproduction of a prescribed source. In contrast, the oral poetry of analphabetic cultures is a technology for the storage and retrieval of cultural memory that involves variance, improvisation, elaboration. In this sense, memorization in poetry is a theatricalization of orality rather than an instance of it. So it's not surprising that, currently, the memorized spoken word is the most marked 'performance' style of poetry presentation, which often resembles an actor's performance (motivated character and all). (124-25)

The language poets' experience as interpreters as well as poets help them to establish themselves as authorities in the field of poetry production and interpretation, which has resulted in their impact on the transformation of the canon.

\section{Reshaping the canon}

In the field of American poetry, the university is a dominant institution with the important function of shaping the poetic canons, which means that "institutional and canonical critique become synonymous" (Golding 149). In this respect, the language poets challenged "almost every aspect of poetic canon formation as it has been historically practiced in the academy" (Golding 145). As has already been mentioned, they managed to establish their own alternative institutions, while at the same time opposing and occu- 
pying the dominant institutions of the academy, which started happening after 1990. The language poets' intention was, like many avant-garde movements before them, to transform the dominant idea of what poetry is as an art. In their theoretical and poetical practice, they reshaped the canon by, on the one hand, focusing attention on the authors, which had not been an important reference for actual poetry practice, and, on the other, by the devices they activated in the process of writing. The poets pointed to European avant-garde poetry movements like the Russian Cubo-Futurism, Italian Futurism, international Lettrism and Sound poetry. Within the context of American poetry, to the main figures of the first modernist wave like Ezra Pound and William Carlos Williams, they added and revived interest in Gertrude Stein as well as the Objectivists, the second wave of modernists, like Louis Zukofsky, George Oppen, and Lorine Niedecker. The heritage of the Black Mountain school, especially the work of Robert Creeley and Robert Olson, as well as the New York school, especially the work of Kenneth Koch and Barbara Guest became important. Their interest also embraced the ethnopoetics of Jerome Rothenberg and the talk poems of David Antin.

In the discourse of poets and critics, the notion of poetry was generally equivalent to the notion of the lyric. This meant that poets in the poem are dealing with a lyrical "I", which emotionally reacts to its environment and the people it interacts with. In this paradigm, the way a poet uses the language is strictly coded as poetical, i.e., different form prose (Đurić 30). Language poets also changed the way of writing poetry. Instead of the lyrical "I", emotional and narrative expressivism, their writing is realized by fragmentation and parataxis, and they have blurred the distinction between poetry and prose writing, destroying the bourgeois aesthetics with its myth of individualism and humanism. Connected with this was the most interesting intervention that was equally found in poetry and in other writings: the blurring of the distinction between poetry and theory. Jed Rasula points out that, in the context of American poetry, "poetic praxis and theoretical examination have rarely been so intimately bound together" (405). This also has to do with the language poets' insistence on "structuralist homology of language and social 
order" (Derkson 125). According to Derkson, the "self-determined individual free to participate in the marketplace" could be understood as the ideal subject produced by neoliberalism (130), which implies the commodification and commercialization of all aspects of contemporary life. In order to oppose this totalizing tendency, language writers started treating language as the site of social engagement. The idea could be recognized in line of the avant-garde as a utopian project. Namely, the idea was to transform the social subject through language and also through the model of reading as productive consumption. So, in the language poets' writing, the poets themselves were produced as a community of active readers of one another's work, and as a reader, every poet could become a member of the community (Rasula 397). In language writing, the poets emphasized the materiality of the text, and the reader became co-producer of the text (ibid.), so that the variety of aesthetic possibilities and methods had a function "to bring reader and writer through language to experience and reconstruct meaning together" (Messerli 8). The question those poets were dealing with was, What is "the place and the nature of writing under capitalism"? (Golding 150), or in Jeff Derksen's formulation: "The question was not just how do you write a lyrical poem after Nixon, but how do you create social meaning during Reagan's time?” (124). In order to answer this question, the important aspect of language poetry practice was to establish the relation "between material text and literary community," and this was done, among other ways, using the strategies of multiple authorship (Watten 2003: 44). In this way, the language poets subverted the idea of the individual writer as a source of literary creativity, as well as the idea of authorial originality. One of the first collaborations I will mention is the project Legend written by Bruce Andrews, Charles Bernstein, Ray di Palma, Steve McCaffery, and Ron Silliman in 1980. In Legend, we find single-authored sentences, as well as texts written by two or three authors writing in the form of dialogic improvisation, as well as multi-authored collaborations. Barrett Watten described five types of texts published in Legend:

1) thematic arguments, 2) the exploration of the signifying potential of spe- 
cific linguistic levels; sentence, phrase, lexeme, morpheme, phoneme, 3) the exploration of the signifying potential of graphic signs, both linguistic and non-linguistic; 4) forms of intertextuality created by mixing modes of signification as they explore the space between subject positions, and 5) dialogic argument. (2003: 64-65)

The second multi-authored work I would like to mention is Leningrad - American Writers in the Soviet Union (1991) written by Michael Davidson, Lyn Hejinian, Ron Silliman, and Barrett Watten. Izenberg characterizes this work as a "narrative' poem, the text documents the meeting of Soviet and American poets. It records their conversation and exchanges, their troubled efforts to bridge the gap that separates East and West, but at the formal level the poem is also a highly self-conscious occasion for a meeting of the American poets themselves" (154-46). Leningrad was written using a complex procedure for exchanging and circulating manuscripts in progress, allowing the poets to respond to one another and revise the text in light of each other's contributions (Izenberg 147).

The last group work I will mention is The Grand Piano - an Experiment in Collective Autobiography, San Francisco 1973-1980, written by the Bay Area Language poets from the 1970s: Bob Perelman, Barrett Watten, Steve Benson, Carla Harryman, Tom Mandel, Ron Silliamn, Kit Robinson, Lyn Hejinian, Rae Armantrout, and Ted Pearson. It appeared in ten volumes from 2006 to 2010. It is imagined as "a vital contribution to the collective memory of the poetry of that period," according to James Sherry, who adds, "This collaborative series explains one group's perspective on the history of the progressive poetry movement of the 70 s and 80 s and as such represents a unique biography. The relations of the individual to the society and its intermediate institutions, such as the Grand Piano readings, is relevant to any thoughtful analyses of the place of poetry writing and production today" (Sherry). 


\section{Global turn and language poetry}

Discussing the global/neoliberal turn in politics, economics and culture, Jeff Derksen stresses the "cultural logic of globalization" with its imposition of "neoliberalism's ideology of economic growth and progress" (Derksen10). This process results in the uneven expansion of economic accumulation, and the economization of every aspect of human life. In this context, Derksen emphasizes:

the fundamental changes that the Language writers present to the social role and production of poetry in a public sphere that was rapidly changing as a result of social disinvestment and the reorganization of the relations of culture and politics of globalization and neoliberalism. (124)

The goal of the language poets was the intended transformation of the social subject through language, which would enable productive consumption, so that the reader is not passive in his/her reception of the already given meaning. The texts have become productive, which means they show to the reader that language is not a transparent medium, which conveys pre-given meaning, but is productive, and in that productivity solicits an active reader as co-producer of the text's meaning. This kind of open text can be understood, according to John Hartley, as a cultural ideological apparatus and enables the reader to "enter into the overdetermined field of language as a productive rather than the interpolated subject" (Derksen 140). But the open text and the production of multiple meanings understood within the context of the post-Fordist flexibility of production and consumption could also be interpreted as an instance of the neoliberal way of production and consumption.

In this regard, we find two opposite approaches to the phenomenon of language writing. One is to consider language writing as a radical poetic movement geared towards larger social struggles, and the other is to consider language writing as complicit with the symptoms of globalization (Derksen125). This contradiction in understanding the work of language poets I 
will leave unresolved.

\section{Works Cited}

Bernstein, Charles. "The Extended Field of $\mathrm{L}=\mathrm{A}=\mathrm{N}=\mathrm{G}=\mathrm{U}=\mathrm{A}=\mathrm{G}=\mathrm{E}$." The Routledge

Companion to Experimental Literature, edited by Joe Bray, Alison Gibbson and Brian McHale, Routledge, 2012, pp. 281-97.

---. "Introduction." Close Listening: Poetry and the Performed Word, edited by

Bernstein, Oxford UP, 1998, pp. 3-26.

---. "Preface." The Politics of Poetic Form: Poetry and Public Polity, edited by Bernstein, Roof Book, 1990, pp. vii-vii.

Damon, Maria, and Ira Livingston. "Introduction." Poetry and Cultural Studies: A Reader, edited by Damon and Livingston, $U$ of Illinois P, 2009, pp. 1-17.

Derksen, Jeff. Annihilated Time: Poetry and Other Politics. Talonbooks, 2009.

Drucker, Johanna. "Visual Performance of the Poetic Text." Close Listening: Poetry and the Performed Word, edited by Charles Bernstein, Oxford UP, 1998, pp. 131-61.

Đurić, Dubravka. Jezik, poezija, postmodernizam: Jezička poezija u kontekstu moderne i postmoderne američke poezije. Oktoih, 2002.

Golding, Alan. From Outlaw to Classic: Canons in American Poetry. The U of Wisconsin P, 1995.

Izenberg, Oren. Being Numerous: Poetry and the Ground of Social Life. Princeton UP, 2011.

Melnick, David. "From Pcoet." In the American Tree: Language Realism Poetry, edited by Ron Silliman, U of Main at Orono, 1986, pp. 90-93.

Messerli, Douglas. "Introduction." "Language" Poetries: An Anthology, edited by Messerli, A New Direction, 1987, pp. 1-11.

Rasula, Jed. The American Poetry Wax Museum: Reality Effects, 1940-1990. National Council of Teachers of English, 1996.

Rothenberg, Jerome. “The Poetics of Performance." The Poetry Reading: A Contemporary Compendium on Language \& Performance, edited by Stephen Vincent \& Ellen Zweing, Momo's Press, 1981, pp. 120-29.

Sherry, James. “Language poetry by the Bay.” Jacket, no. 34, 2007, 
jacketmagazine.com/34/sherry-piano3.shtml. Accessed 9 August 2016.

Silliman, Ron. The New sentence. Roof, 1987.

---. Tjanting. The Figures, 1986a.

---. "From The New Sentence." In the American Tree: Language Realism Poetry, edited by Silliman, U of Main at Orono, 1986b, pp. 561-75.

--. “Language, Realism, Poetry." In the American Tree: Language Realism Poetry, edited by Silliman, U of Main at Orono, 1986b, pp. xv-xxiii.

Watten, Barrett. The Constructivist Moment: From Material Text to Cultural Poetics. Wesleyan UP, 2003.

---. "Language Writing." The Cambridge Companion to Modern American Poetry, edited by Walter Kaladjian, The Cambridge UP, 2015, pp. 234-47.

Watkin, William. "Projective Recursion: The Structure of Ron Silliman's Tjanting. Jacket no. 39, 2010, http://jacketmagazine.com/39/silliman-watkin.shtml. Accessed 9 August 2016.

Williams, Raymond. Marxism and Literature. Oxford UP, 1977. 